\title{
GHOSTLY ALLEGORIES: HAUNTING AS CONSTITUTION OF PHILIPPINE (TRANS) NATIONAL (CINEMA) HISTORY
}

\author{
Patrick Campos \\ University of the Philippines Film Institute \\ patrick.campos@gmail.com
}

\begin{abstract}
By reading through the con-texts of Yam Laranas's The Echo (2008) and Kelvin Tong's The Maid (2005), the essay considers three Filipino genres that ironically gathered momentum at the time of the Philippine film industry's crisis and decline in the 1990s up to the 2ooos - the historical drama, the OFW (overseas Filipino worker) film, and horror. In the process, the essay constitutes an alternative map of Philippine cinema premised on inter-national transactions across states and film industries, on the one hand, and on the nodal and spectral bodies of Filipinas that network these states and industries, on the other hand. Dwelling on multiform hauntings, it ultimately focuses on how nations/cinemas - through (de)localized genres - are constituted and called into account by specters of (cinema) histories.
\end{abstract}

\section{Keywords}

Philippine cinema, Singapore cinema, transnational cinema, Asian horror, OFW film

\section{About the Author}

Patrick Campos is Assistant Professor at the University of the Philippines Film Institute. He is currently Director of the Office of Extension and External Relations of the College of Mass Communication, University of the Philippines, Diliman, where he previously served as College Secretary. 
I came here to see the world. I ended up looking into the saddest and darkest part of the human heart. Here my journey ends. I am finally going back. And so is another girl who has been away from home for a long, long time.

-Rosa Dimaano in The Maid

The willingness to follow ghosts, neither to memorialize nor to slay, but to follow where they lead, in the present, head turned backwards and forwards at the same time. To be haunted in the name of a will to heal is to allow the ghost to help you imagine what was lost that never even existed, really. That is its Utopian grace: to encourage a steely sorrow laced with delight for what we lost that we never had; to long for the insight of that moment in which we recognize, as in Benjamin's profane illumination, that it could have been and can be otherwise.

\section{-Avery F. Gordon, Ghostly Matters}

\section{Haunting and the Fantastic}

By reading particular cinematic texts alongside their historical, discursive, and fictive con-texts, the essay aims to bring a polysemic notion of "Philippine cinema" into dialogue with other conceptions of cinematic formation and to map out the multifaceted but interconnected fantasies that their dialectics embody. I reflect upon two films, in particular The Echo (Yam Laranas, USA, 2008) and The Maid (Kelvin Tong, Singapore, 2005), both of which occasion the problematization of the interrelated ideas of the "national" and the "trans-national" as they shed light, or cast their shadows, on Philippine (film) history. By reading "con-texts," I mean to signify a cleft in the conventional configuration of text/context. ${ }^{1}$ I read as texts, and not just as backdrops, the critical and popular registers of the perceived place of the films in the national-transnational continuum of cinematic formation. More important, I read as texts intimations of inter-national transactions across states and industries premised, on the one hand, on the globalization of cinema and, on the other hand, on the nodal and spectral bodies of Filipinas that network these cinematic texts and their con-texts.

By constituting a Philippine cinema imaginary through films produced outside of the Philippines, I acknowledge the tactical necessity of the shift of focus in film studies from the national to the transnational as a locus for inquiring about cinema. Such a shift in critical paradigm is able to account for the flow of multiand inter-national capital, the deregulation of markets and creation of "alternative 
economies," the interpenetration of communication networks across cultures, and the increased mobility of "ghost labor" and bodies across territories (cf. Comaroff and Comaroff) - all of which have transformed the processes, practices, and perceptions of cinema and nation.

But the need to maintain "nation" as a unit of political, economic, and cultural differentiation remains urgent, precisely because it is always caught in conceptual slippages - such as, trans-national, inter-national, sub-national, post-national, multi-national, cosmopolitan, global, world, planetary, scalar, regional, diasporic, ethnic, inter-cultural, multi-cultural, colonial, neo-colonial, and post-colonial - that seek to account for the complex systems that operate historically within, through, between, and above individual nations, ultimately affecting individual national subjects (cf. Hjort and MacKenzie). In both the cultural articulations and the institutional practices that materialize cinema, there remains, therefore, an ironic but pressing need to sustain the phenomenon of nation against global perils that also sustain it (cf. Berry). As I hope to show, the markers of nationality in certain configurations of transnational films alert us to the ambivalent meanings and conflictive uses of nation.

My critical project is buttressed by Bliss Cua Lim's thoroughgoing deployment of "fantastic cinema" as ontological and postcolonial critique of "modern homogeneous time," which reduces history to the imperial function of "progress" (43-95). I return time and again to her notions of the spectrality of time as crystallized by ghost films (149-89) and the ghostliness of genre as conventionalized by the Hollywood remakes of "Asian" horror films (190-244) in my own analyses of the texts and contexts of Laranas and Tong. The relationship between the sections that follow below are con-textual and spectral as well, rather than merely linear and sequential; they are unrelated, in one sense, but they occupy the space of comingling ghostly allegories that render Philippine (trans)national cinema perceptible. Drawing upon Lim's insights, ultimately, I focus on how nations/cinemas can be constituted and called to account by the specters of (cinema) histories.

\section{American Fantasies and Philippine Film Culture}

The 2008 Hollywood release of The Echo by Filipino director, Yam Laranas, clears the locus for us to consider Philippine cinema as "transvergent" (Hunt and Leung $3),{ }^{2}$ at the same time as the specter of the Filipina in the film's fiction allows us to witness "history as haunting" (Lim 170). The Echo, which is a remake of Laranas's Sigaw [literally "scream"] (2004), is a consummation of the Filipino filmmaker's fantasy to have the stage and the audience of the American market. Such a fantasy, according to Jose B. Capino, is one of the many permutations of "American fantasies," or "transcultural imaginings defined by an American presence" (xviii), generated by Philippine cinema - the "dream factory of the former colony." In what follows, I locate the interior and exterior narratives of The Echo within the spaces of local 
film culture, in order to constitute Laranas's and the film's arrival in Hollywood as a ghostly return of history.

In 1997, the Asia-wide economic crisis dealt a deathblow on Philippine cinema, which, earlier in the decade, was already experiencing a pronounced weakening in terms of box-office returns (Tiongson 4). This weakening was, in fact, state-sponsored, when, after decades of uninterested and tractable support on local cinema, the Philippine government endorsed the General Agreement on Tariffs and Trade (GATT) in 1993, thereby allowing the unrestricted entry and dominance of Hollywood films in the country. From a leading national film industry in Asia (in terms of quantity, at least) that produced several hundred movies a year, Philippine cinema steadily declined in its annual mainstream output at the turn of the current century, with 103 films produced in 2001; 94 in 2002; 80 in 2003; 55 in 2004; 50 in 2005; and only 48 in 2006. ${ }^{3}$ The years leading up to, and following, the 1997 crisis concomitantly saw the exodus of more and more Filipinos seeking employment "overseas" (Orbeta and Abrigo). Meanwhile, and ironically enough, three film genres gathered relative momentum in terms of number of either production or popularity during this juncture in (film) history - the historical drama, the "OFW" (overseas Filipino worker) film, and horror.

The marked increase of the production of historical dramas beginning in the $1990 \mathrm{os}$ celebrated national heroes and commemorated the centennial of the Philippine revolution against Spain in 1896 and the declaration of Philippine independence in 1898. Some of these films include Raymond Red's Bayani [Hero] (1992), Carlo J. Caparas's Tirad Pass: The Last Stand of General Gregorio del Pilar (1996), Tikoy Aguiluz's Rizal sa Dapitan (1997), Jose Mari Avellana and Joey Romero's Emilio Aguinaldo (1998), Jose Mari Avellana's Damong Ligaw [Stray Grass] (1998), Mario O'Hara's Sisa (1998), and Marilou Diaz-Abaya's Jose Rizal (1998) (see Figure 1). These historical films about national triumph and liberty from colonizers are doubtless haunted by the actual turn of events: all the heroes exalted in these films are, of course, tragic figures; there had been no real independence in 1898, since America violently annexed and pacified the islands with the force of an all-out genocidal war. Philippine (film) history has, since then, been indelibly tainted by the physical and epistemological violence of American colonial rule.

The early initiation of the Philippines in the project of nation-building and its subsequent "tutelage" under the US find a distinct outworking in the formation of "national" cinema. Among many other consequences, this intersection of the histories of the aborted nation and the new empire - with the Philippines barely out of the throes of the first anti-colonial revolution in Southeast Asia, while America was at the onset of enacting its imperial fantasies - burst open, on the one hand, a dam of American ("junk") films, flooding local screens even before Hollywood ever achieved worldwide dominance (Deocampo, Film 178-83) and, on the other hand, channels of migration, allowing for increasing waves of Filipino workers to resettle in the US (cf. San Juan, From Exile). A remarkably early figuration of 
these two consequences of colonial ties (i.e., Hollywood influx and migration to the US) is the activation of the fantasy to adapt Hollywood processes to local film culture and the fantasy of film artists to migrate to Hollywood (Deocampo, Film 413-34), exemplified in the person of the "other' father of Philippine cinema," Vicente Salumbides (cf. Villasanta). ${ }^{4}$ Salumbides, considered the progenitive hero of a Hollywoodized Philippine film, directed Miracles of Love (1925), patterned after American romance, employing classical Hollywood film codes, and featuring the "American beauty" of Elizabeth "Dimples" Cooper (Deocampo, Film 476; Pilar 2474; Hawkins 107; cf. Salumbides). Trained in the US, Salumbides initiated and instantiated how American fantasies "are rewritten, indelibly marked, recirculated, or conjured by Filipinos" through "processes of appropriation and cultural translation" (Capino xviii). Such fantasies have surfaced, across the decades, in the fanfares that characterize popular commentaries and journalistic features on the forays of local actors in Hollywood movies, such as Barbara Perez in No Man is an Island (Richard Goldstone and John Monks Jr., USA, 1962) and Cesar Montano in The Great Raid (John Dahl, USA, 2005) (see Fig. 1), or on Hollywood location shooting in the Philippines (e.g., Apocalypse Now [Francis Ford Coppola, USA, 1979] and The Bourne Legacy [Tony Gilroy, USA, 2012]).

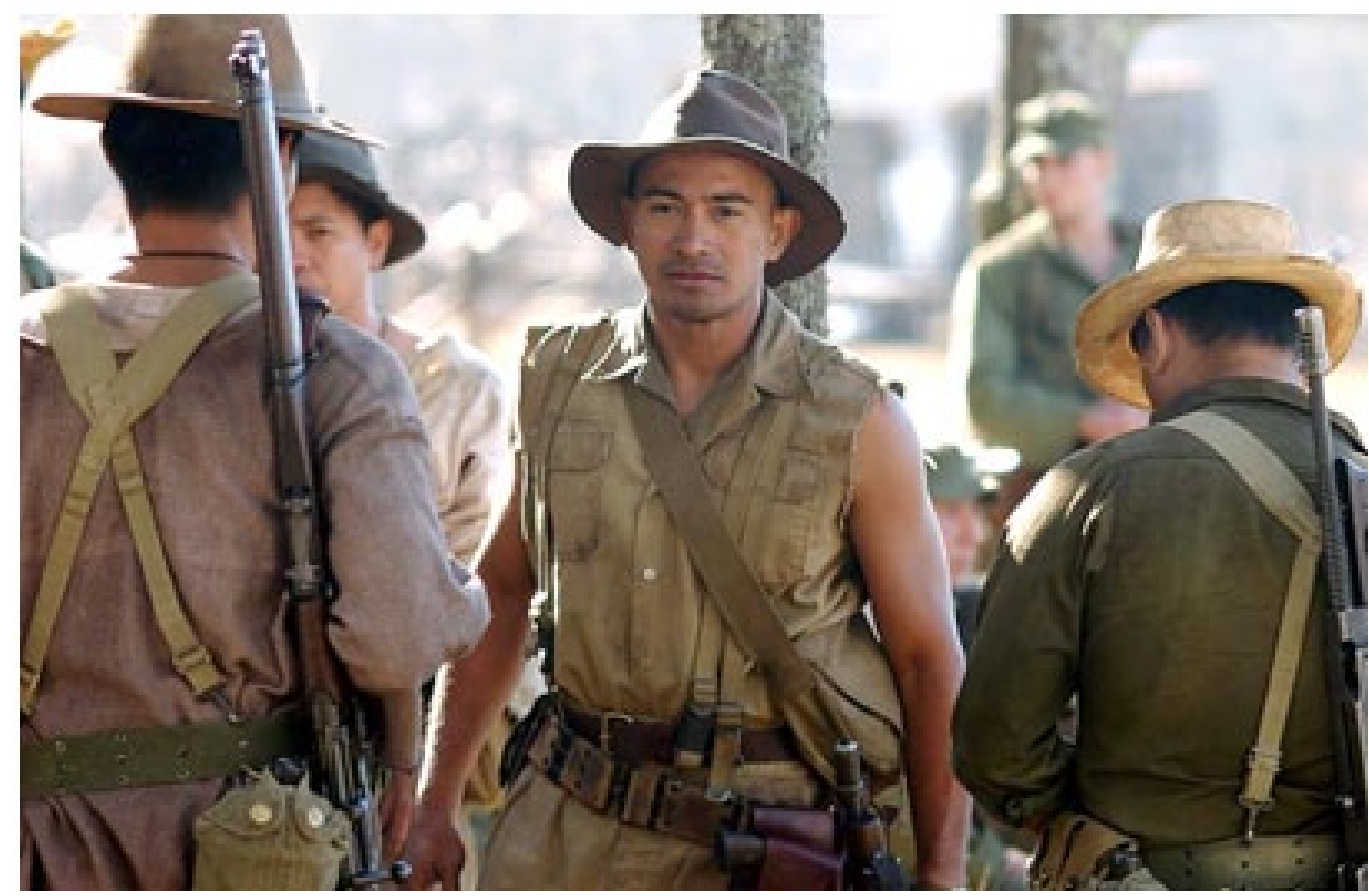

Fig. 1: Cesar Montano, who plays the national hero in Marilou Diaz-Abaya's Jose Rizal, plays a minor role as guerilla leader, Juan Pajota, in the Hollywood film, The Great Raid, about the liberation of POWs in Japanese-occupied Cabanatuan, Philippines, during World War II. Publicity photo from Cineplex.Com. ${ }^{5}$ 
These fantasies, initiated upon Philippine-American colonial contact and amplified by Hollywood's eventual rise to dominance, are what continue to inform the perceived importance of Laranas's arrival in Hollywood via The Echo. Over the last fifteen years, according to Toby Miller et al., at exactly the juncture when Philippine cinema spiraled down in productivity, "global Hollywood" has, meanwhile, doubled its share of the international market, demanding between 40 to 90 percent of national box office revenues around the world (Miller et al.). Along with the neoliberal campaign of the US in the GATT and, later, the World Trade Organization, the American film industry has exerted tremendous pressure on international competitors, worked to eliminate the safeguards of other national markets, strengthened its grip on global distribution and exhibition, imported and outsourced talents, appropriated "foreign" genres, and remade box-office hit films from other regions (Hjort and Petrie, "Introduction" 8; cf. Xu; Lo). It is against this Hollywood hegemony that we can, therefore, understand the fantasies that engendered Laranas's Sigaw and The Echo and the rise of horror film production in the Philippines after the period of the centennials of the Philippine revolution and independence.

\section{The Horror Film Cycle}

The proliferation of horror films in the Philippines at the turn of the century is contemporaneous with what Lim characterizes as the "Asian horror remake frenzy" in Hollywood which began around 2001. In 2003, according to her, "at least 18 remakes of films from South Korea, Japan, and Hong Kong were either completed or in the works at various studios," spearheaded by Dreamworks' phenomenal, The Ring (Gore Verbinski, USA, 2002), based on Ringu (Hideo Nakata, Japan, 1998). And, by 2004, the year of the local release of Laranas's Sigaw, "the [horror remake] cycle's momentum [was] still unchecked" (Lim 194).

Meanwhile, from about 26 Filipino horror films produced in the decade of the 1990s, ranking as the least popular film genre of the period according to Nicanor Tiongson, the number rose to nearly 70 in the first decade of the 2000 ("The Best" 22; IMDB.com). Three of Chito S. Roño's films, produced by the leading mainstream studio in the Philippines, Star Cinema, were record-grossing upon release, Feng Shui (2004), Sukob [The Wedding Curse] (2006), and Tenement 2 (2009). Sukob, featuring local superstars, Kris Aquino and Claudine Barretto, had the distinction of being the highest-grossing Philippine movie at the time, a rare achievement for a horror film which typically attracts select audiences. It also spawned a spoof, Pasukob (2007) by Wenn V. Dermas (see Figs. 2 and 3), signaling a saturation point for the genre. Feng Shui, also starring Kris Aquino, was one of the earlier phenomenal hits that fueled the Philippines' own horror cycle, and its entry in the user-generated Wikipedia has an ironically painful and perhaps unintentionally humorous line that betrays the fantasy of local film culture; it reads, "The Hollywood version of the 
movie [Feng Shui] is still frozen and it is unknown if Star Cinema have [sic] decided to have a contract with Hollywood."
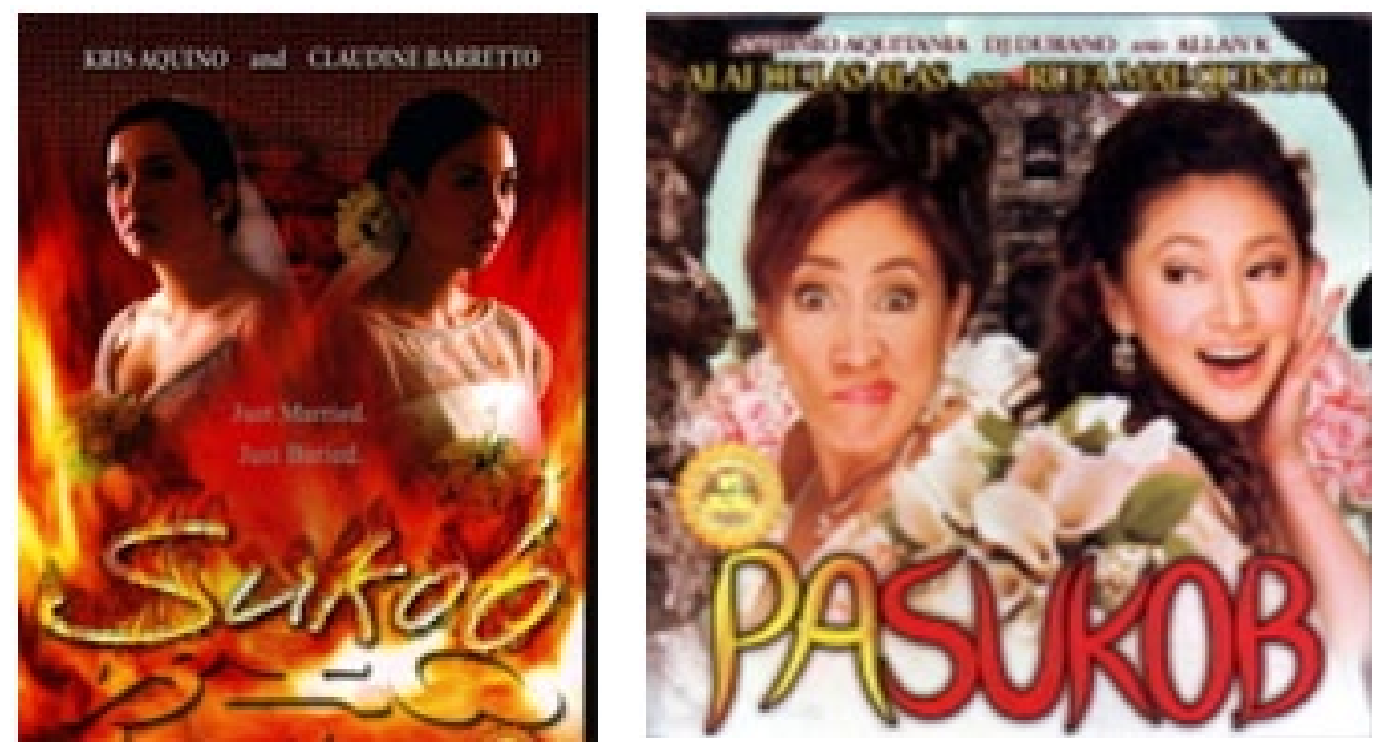

Fig. 2 \& 3 : (Left) Sukob, a Philippine film in the "Asian horror" vein, was the highestgrossing movie in the Philippines in 2006. (Right) Pasukob was a spoof of Sukob, signaling the saturation point of the local market. Publicity photo from KababayanCentral.Com. ${ }^{7}$

Many of the horror films of the 20oos - especially when compared with horror films prior to the regional-transnational remake cycle, for instance, by Peque Gallaga and Lore Reyes, in the 1990 - have visibly begun to cannibalize and reanimate with half-lives the conventional iconography of "Asian" (rather than "Philippine") horror (cf. Lim; Xu). The Philippine horror cycle, therefore, is in large part defined by Hollywood hegemony, and its rise and decline, its genesis and expiration date, are inextricably linked with the Asian horror remake trend. As Lim writes of the horror cycle configured according to the logic of "generic repetition" and Hollywood's "remake time,"

We are faced, on the one hand, with the force of singularity: the singularity of the jolt, of the first time one sees a ghost, or screams at a terrifying turn in a movie. On the other, formulaic repetition: one sees the same ruse again and again. A scream gives way to a chuckle; the horror film fails to horrify, losing the affective charge for which the genre was named. The ghost becomes generic, the very figure of genre. Through singularity and repetition, the ghost figures both the force and depletion of return. (219-20) 
It is this "remake time" that distinguishes the timeliness of Laranas's celebrated Sigaw in 2004 and the lateness of The Echo's (non-)arrival in the American market in 2008. As of June 2007, a year before The Echo's release, Los Angeles Times already declared that the "chill is gone" (Abramowitz and Crabtree n.p.). Lim, describing the saturation of the market, writes, "Forty-some horror films were released [in America]..., more than doubling the numbers for the year before," and she notes, too, that fan reviews have begun to "sound an unmistakable note of exasperation ranging from skepticism to outright resistance - in relation to Hollywood remakes" (Lim 199). This was the context of The Echo's arrival in America, where it did not get a full theatrical release but, instead, went straight to video.

Chronicling the journey of his original Philippine production, Sigaw - through the travails of guerilla marketing via the internet; 8 its local patronage by Filipino cineastes during the annual Metro Manila Film Festival; the critical attention it garnered in Screamfest L.A. International Horror Film Festival and CineAsia Film Festival in Cologne; the announcement that Vertigo, the company that began the remake practice of Asian films in Hollywood, was interested in buying it; the drumming up of its coming in special interest user-sites, such as PinoyExchange. com and IMDB.com; the labors of rewriting its script and changing its cast and location; and the obstacles of its principal photography and postproduction until its arrival in the US as The Echo, the blog of Laranas himself, Yamlaranas. blogspot.com, ${ }^{9}$ from 2005 to 2008 , provides a fascinating peek at the dynamics of fantasy-production. ${ }^{10}$

In the blog entries and the comments section, Laranas is cast as a heroic underdog by fans and followers ("not bad for a largely unknown filmmaker from the Philippines"), as he narrates himself as the protagonist in an odyssey, responding to a beckoning ("my only objective is...to make all fans of horror movies happy"), weighing decisions ("I was reminded...producers make the final decision...in the remake of my own movie"), overcoming obstacles ("a rough start because of some unexpected delays that's beyond our control... always pressed for time"), and finally arriving ("It is done. The Echo is now getting ready for the world") ("Laranas Blogspot"). Some of his admirers exalt his heroic figure by likening him to Hollywood director Martin Scorsese, and by cheering on local celebrities as prospective actors in the remake, especially Richard Gutierrez (imagined as Hollywood actor, Leonardo di Caprio, to Laranas's Scorsese) and Iza Calzado, both of whom played lead in Sigaw ("Laranas Blogspot"). The heroic configuration of Laranas as film director and as Filipino is ultimately conflated in many of the comments, as when one user (text uncorrected) writes,

Sir Yam,

I still don't know you that much. But I can feel how dedicated you are in your craft and how committed you are to make our country very proud in abroad specially in Hollywood. Recently, you are one of the few good news that 
are happening now in the country. You simply kill those daily political and economic problems, those killings and accidents, those kidnappings and drug syndicates. We hope to hear more of what you're doing not for yourself and for your family, as well as for our country. [...] We are here for you. ("Laranas Blogspot" n.p.)

Laranas's blog also fleshes out the contours of the historical narrative of the Filipino diaspora: Filipinos are now spread all around the world, and yet the fantasy of progress in the US, associated with the grandeur of Hollywood, remains primal and the basis for an ambivalent urgency for unity. "We are here for you," concludes the above comment, signifying solidarity. "We are proud to be Filipinos" is one of the patriotic refrains throughout the five years' worth of comments in Laranas's blog pertaining to Sigaw and The Echo. Indeed, a remarkable feature in the comments section of Laranas's blog is the motif of the "kababayan" (compatriot), registered as writing from places like Manila, New York, Toronto, Sydney, Madrid, expressing oneness with a fellow Filipino, wherever they may be located ("Laranas Blogspot").

Following Capino's arguments, the production by a Filipino of a Hollywood genre spectacle is significant since, generally, former colonies of the US "remain practically invisible in Hollywood pictures," even while "Americans and the states have kept their place as the primary others and elsewheres in Philippine cinema $[\ldots]$ not only in the diegesis of the films but also in aspects that are less visible or remain entirely offscreen" (xviii). This "invisibility" from Hollywood screens is doubly significant when one considers a motif in the works of a number of AsianAmerican critics - that while the migration of Filipinos to the US was initiated by the violence of colonization and has continually been sustained by what Yen Le Espiritu calls "differential inclusion," Filipino-Americans "are still practically an invisible and silent minority" (San Juan, "Mapping" 117) and remain to be the "forgotten Asian Americans" (cf. Espiritu; Campomanes; San Juan, From Exile; Cordova). Differential inclusion, according to Espiritu, is "the process whereby a group of people is deemed integral to [America's] economy, culture, identity, and power $[. .$.$] precisely because of their designated subordinate standing," precisely$ "because they are not fully present," i.e., they remain spectral (47; cf. Said).

\section{Ghostly Allegory 1 - The Echo}

This continued violence wrought upon the former colonial, and now neocolonial and also migrant, subject is allegorically played out in the ghost tale that is The Echo. Shedding almost entirely the middle-class issues of Sigaw, The Echo robes itself with the appearance of a racial-historical critique. The story is set in a decrepit and haunted New York apartment, where a recently freed ex-convict, Bobby, gradually discovers the reason for his mother's mysterious death while he was in prison. Upon his occupation of his mother's apartment room, Bobby begins to be disturbed by 
noises. First is the kind of noise that he hears outside, from the adjacent room, every night, where a policeman and his wife and daughter live - loud arguments, screams and pleas, banging and hitting. Second is the strange and unexplainable noise that he hears inside his own room. The constancy of the disturbances begins to agitate him and affect his relationship with his girlfriend, Alyssa.

He confesses to Alyssa that he is beginning to understand what happened to his mother, because, like his mother, he has begun to hear noises in his head. This explanation, of course, is not complete, because it does not precisely answer why he hears the noises in his head, or even how. The din just creeps into one's head, he thinks, as it crept into his mother's head repeatedly and long enough until it killed her. Meanwhile, it had not occurred to him that the racket made by the family in the other apartment had anything to do with his inner torment, an inner conflict born out of the guilt of a parent. He is unselfconsciously impelled to intervene, whenever he hears the violent beatings followed by cries of pain and terror. Once, he bangs on their door to break up the fight, and the policeman threatens him to "mind your own business." At another time, he lets their daughter into his room to shield her from the dread.

As he begins to meddle in the affairs of his neighbors, he comes upon the dual revelation that the adjacent room has been empty for years and that the "social" and "psychological" noises that continue to torment him are one. The external violence has been interiorized, both literally (with the terror from the other room entering his own) and figuratively. He learns from another tenant in the apartment, who is subsequently killed by the vengeful ghost, that years ago, indeed, there lived a family in the now-empty room, where a policeman beat his wife to death when she tried to escape their abusive relationship. And no one in the apartment building, including Bobby's mother, risked comfort to help the wife when she wanted out.

Here on, the understanding becomes gradually complete, as the terror that he hears in his head is revealed, coded by generic horror, as a call for justice and a clean break. The helpless woman who has been screaming for help, night after night, reveals herself to him in his very own room, face to face, as a bloodied apparition

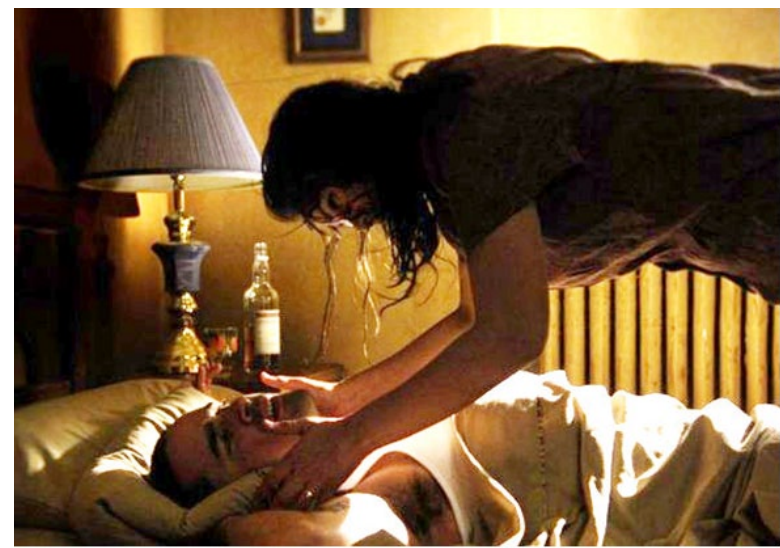

of a Filipina (see Fig. 4). Bobby had seen her before, this Filipina, rapping at his door, begging for help.

Fig. 4: The ghost reveals herself to Bobby - as a dream, as a vision, as a reality - in his very own room, face to face, as a bloodied apparition of a Filipina. Publicity photo from Aceshowbiz.Com. ${ }^{11}$ 
Gary G. Xu argues that changing the ethnicity of the characters in Hollywood remakes, from Asians to white actors, serves to conceal the intensive Asian labor that America outsources and profits from (196). This relates to Lim's assertion that "any notion of the distinctiveness of national cinema (whether formal, cultural, economic, or historical) must contend with Hollywood's voracious capacity to deracinate - that is, uproot, efface, and delocalize - such forms of distinction" when a film is remade (Lim 199-200). Laranas himself, in his blog, claimed, "I have no intentions of portraying Filipino elements in this movie. I just want to make a horror film - that's all." And most of the comments in the same blog pertaining to the casting of Iza Calzado, a Filipina mestiza, as the abused wife in The Echo, were concerned with notions of stardom and breaking into Hollywood.

But the revelation in the film that the battered woman is a Filipina actuates the haunting of history. The very body of Calzado bears the specter of history. When the ghost, played by Calzado, begins to follow Alyssa even beyond Bobby's apartment, her brown skin, her height, and her shabby (not necessarily ghostly) clothes immediately set her apart from the crowd of well-dressed white people who neither see nor sense her presence (see Figs. 5 and 6). The haunting takes on a racial-national marking and allegorizes the tale, thereby "redeeming for the present' a past whose relevance is in danger of vanishing by inscribing it anew" (Lim 156). As ghostly (trans)national allegory, the haunting is reckoned not only to be about the abstractly universal despicability of social apathy and unaccountability, but also, damningly, about the specific sustenance of a national-racial relations of violence throughout history.
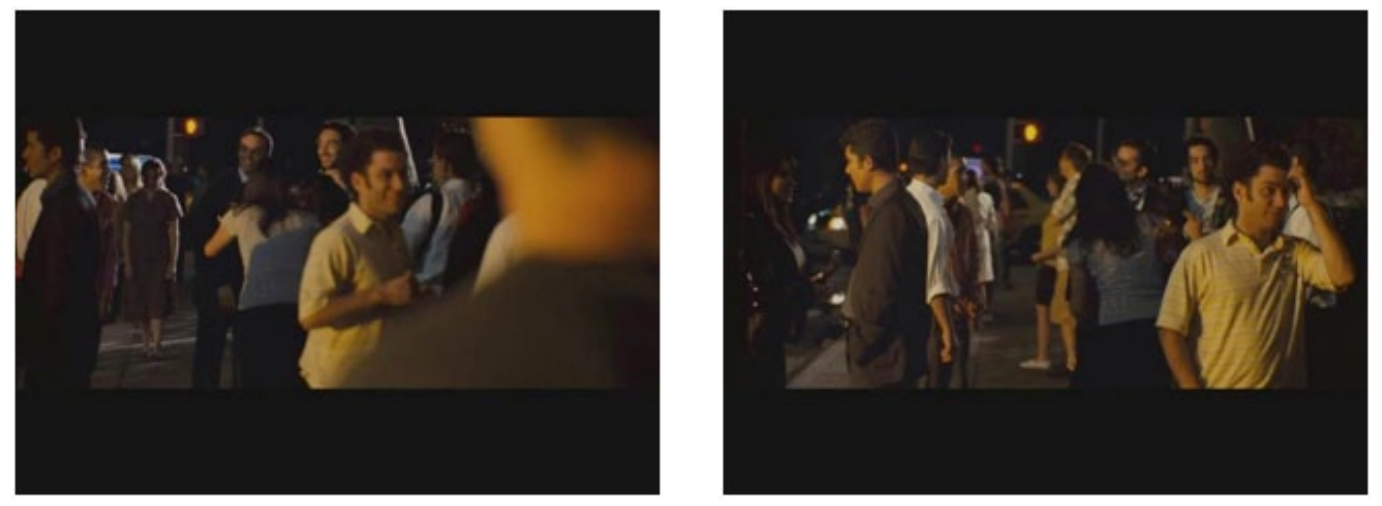

Fig. 5 \& 6: On the left, the Filipina ghost walks among white people in New York City. On the right, she suddenly disappears, and, yet, none of the people sees nor senses her presence/absence. Screencaps by the author. 
Space in the ghost film is heterogeneous (175), argues Lim. The odious apartment building, which also signifies the sinister side of apathy and unaccountability, becomes the site of "traces and remains." The unraveling of heterogeneous space is co-incidental for Bobby and the spectator. Bobby watches as these two racialized and nationally-marked bodies come face to face before the fateful violence that ultimately leads to the Filipina's death. When she is confronted by her husband, the policeman in uniform is portrayed, beside her, as a pale white and towering browbeater, a man of the law who is also the perpetrator of crime (see Figure 7). This is the PhilippineAmerican point of contact. This is a "haunting repetition of a traumatic past," a primal moment which "comes to be experienced with the 'singularity' of the 'first' time" (Lim 151). And here it is Bobby who is given the chance to turn back time, as it were, to act justly against his own interests, comforts, and safety, to be accountable, and, allegorically, to answer to all those who have been oppressed and "who are no longer with us, a solidarity with specters made possible by remembering” (Lim 181).

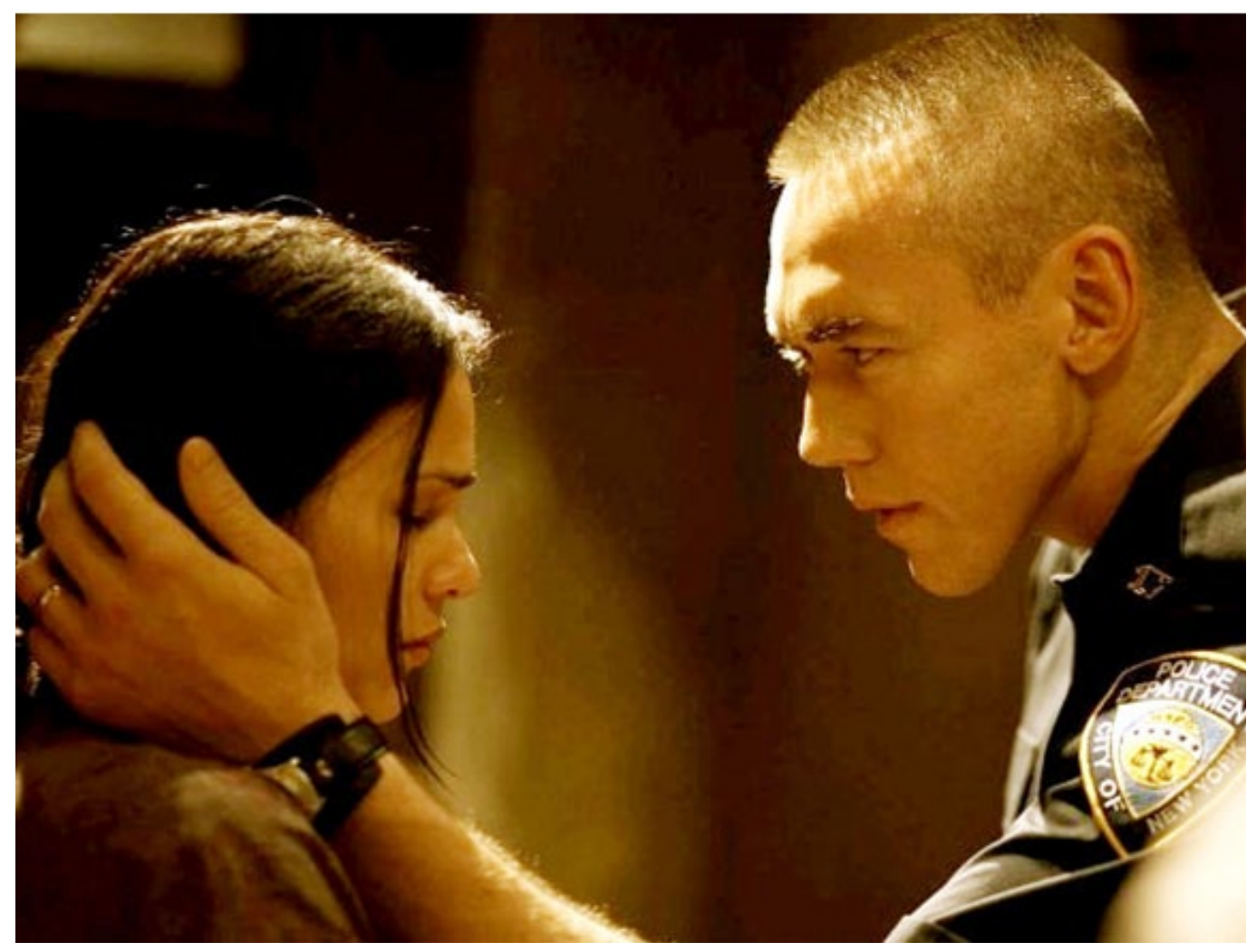

Fig. 7: The American policeman (Kevin Durand) confronts his Filipina wife (Iza Calzado), before he beats her to death for trying to escape. Publicity photo from Aceshowbiz.Com. ${ }^{12}$ 
In this final moment of screen time, which is a moment in the ghost narrative that has been repeated indefinitely outside of time, the body is bared to co-exist as multiple specters beside itself - the long dead Filipina and now returning ghost, the still alive immigrant pleading for another chance to escape, and, by film's end, when Bobby intervenes - in the spatial sense of coming in between aggressor and victim and in the temporal sense of being caught between two periods of time - the ghost, embodied and enabled to fight back, save her daughter, and live. In this moment, when the "ghost calls us to a radicalized conception of historical justice" (Lim 179), Bobby responds.

The arrival of The Echo, then, could be understood as a return of history and a call for "historical accountability," which is "a matter of being responsible, not merely to the past but also to noncontemporanaeity, to the ghosts who perturb the present with their simultaneous presence and absence, making a simple fenced-in present impossible" (Lim 180). This particular ghost tale's arrival in Hollywood could be no mere American fantasy; it could be an occasion "[to] exorcise not in order to chase away the ghosts, but this time to grant them the right $[. .$.$] to[...]a$ hospitable memory[...] out of a concern for justice" (Derrida 175). Uncannily, The Echo fell out of synch with remake time and, even as commodity, was rendered practically invisible in American film culture.

\section{Global Fantasies and Regional (Trans)nationality}

The specter of another Filipina haunts the transnational screen, as she appears as Rosa, played by Alessandra de Rossi, in the Singaporean film, released a year after Sigaw and three years before The Echo. Kelvin Tong's The Maid is also possessed by the ghostliness of genre and more explicitly defined global fantasies. Its being a ghost film simultaneously reflects and embodies the anxieties of marking itself and the cinema from whence it emanates nationally and transnationally, while the ghost of its narrative haunts the very foundation and location of its cinema's (trans) nationality.

The Maid, in the imaginary of Singaporean cinema, is an exceptional film, both for its commercial success and its supposed cultural specificity. A smash hit in Singapore, earning a record amount of $\$ \$ 758$, ooo on its opening weekend alone and distributed internationally by Fortissimo, it has been played up in the local press as a "global break out movie" (Tong, “The Maid 女佣 Media Reports"). ${ }^{13}$ The media hype generated by The Maid betrays the American fantasies behind its production and distribution that likewise inspirited the pomp of Laranas's arrival and the spate of Filipino horror films. In a magazine article which came out around the time of the film's local release, Jeanine Tan envisages, through the promise of The Maid, a time when a Singaporean film could end up like My Sassy Girl (Kwak Jae-yong, South Korean, 2001), which was able to breakthrough cross-regional markets; or, "taking the dream a little further," she writes, when a Singaporean film 
could possibly be "picked up by Hollywood," like "numerous Japanese horror films" before it (Tong, “The Maid 女佣 Media Reports”). In a later, more celebratory article, Jeanine Tan writes of how "the success of Singapore horror film The Maid has attracted the attention of Hollywood," with companies Plan B, New Regency, Vertigo Entertainment, and Red Wagon Entertainment, inquiring about its remaking rights; though it was never remade (qtd. in Tong, “The Maid 女佣 Media Reports").

This celebration of the "breaking out" of The Maid is predicated on its being a "Singaporean" (i.e., nationally marked) film, understood in the unique context of Singapore's "young" and "small" transnational cinema (cf. S. Tan and Fernando). A standard historical account of Singapore cinema is chronicled by Jan Uhde and Yvonne Ng Uhde. They date its "golden age" from the 1940s to 196os, with the mostly Malay-language films produced by the Shaw and Cathay-Keris studios; its "dark ages" from the 1970s to the 1990s, when the struggling nation produced no significant film; and its "rebirth" in the 1990s, when the Singapore state, even in the midst of the 1997 Asian crisis, began to show renewed support for local media (Uhde and Uhde). But Singapore, as a "nation," only declared its independence in 1965, which renders its early years of cinematic productivity as retrospectively transnational. And Uhde and Uhde's historicizing is disputed by Sophia Siddique, who claims that such an account overlooks the generally un-historicized "grassroots" cinema of the 1980s, and by Ruth Bereson, who asserts, contrarily, that there has never been a real "rebirth" in the 1990 os and that this idea is only the creation of a state-sponsored rhetoric (cf. K. Tan 42).

But even with such a resurgence, not least because of its being a cinema of a "small" nation, as See Kam Tan and Jeremy Fernando conceive it, Singapore cinema of the last decade has been decidedly transnational. This transnationality, epitomized by the processes of Singapore's premier studio, Raintree Pictures (also known as MediaCorp Raintree) and evinced by state and industry discourses from the mid-1990s to the 200os, keeps in abeyance, at the same time renders desirable, the national-marking of individual films. In 1998, the same year as the establishment of the Singapore Film Commission, Raintree Pictures was founded as the filmmaking outfit of state-controlled media company, MediaCorp, with a stake in the state fantasy of turning Singapore into a "Global City for the Arts" and a "Renaissance City" (K. Tan 42-45; S. Tan and Fernando 131-32; cf. MICA). Since then, it has (co-)produced more than 30 films, accounting for roughly 40 percent of the national cinema output since 1991 and dominating domestic market share by about 60 percent (S. Tan and Fernando 132).

In its corporate profile, ${ }^{14}$ Raintree Pictures positions itself as the producer of "'borderless' movies for the international viewer, [...] with a sensibility that is truly universal for the viewer who speaks any language." This self-conception of borderlessness is translated into "local" productions, patronized mainly by a domestic audience and "regional" co-productions marketed internationally (S. Tan 
and Fernando 133; cf. Millet). An example of the former are the films of Jack Neo, while of the latter is The Eye, a 2002 horror film co-produced with Hong Kong, shot mainly in Thailand and Hong Kong by the Pang Brothers, co-starring Taiwanese actress, Angelica Chan, and remade in Hollywood in 2008.

Regarding the practice of transnational co-production, S. Tan and Fernando tellingly remark that "the extent to which Raintree Pictures has creative control over its regional co-productions is unclear and in all probability, its influence is not significant" (134). Meanwhile, Daniel Yun, CEO of Raintree Pictures, characterizes the company's transnational priorities while self-deprecating the national cinema, thus:

I'm looking at Asia - and beyond - as a market [.... It's a blinkered point of view to think of a Singapore film only as one that's by and for Singaporeans. We [Singaporeans] have to broaden our view. I'd say a film is Singaporean if at least a quarter of the investment is from here and/or there's a meaningful involvement in front of or behind the camera. (qtd. in S. Tan and Fernando 134)

In separate occasions, Yun further describes the two-sides of the company's motivation for entering mainly into co-productions: on the one hand, he said, "We [have] walked away from movies that are too local to travel," while, on the other hand, he claimed that on its own, Singapore does not "have the heritage here, we don't have the expertise" (K. Tan 49).

Clearly, a transnational imaginary, rooted in market economics and state rhetoric, informs both the concept of Singapore as global city and Raintree Pictures as global film producer. ${ }^{15} \mathrm{~S}$. Tan and Fernando locate the contested "nation" in between the tensions of "cultural nationalism" and "technocratic nationalism" (12734). They write,

Singapore's legacy as an entrepôt port is crucial, and consequently, conceptions of film as merchandise for transnational transaction become dominant, while questions of culture, or of cinema as having cultural currency, have taken a back seat. However seemingly opposed, these two kinds of nationalism are not always mutually exclusive. Technocrat nationalists have as much of a vested interest in the nation's self-image as cultural nationalists; both are concerned with the matter of national specificity in Singaporean films. (128)

Considered against such discourses, it is no wonder that the commercial success of Raintree Picture's "homegrown" The Maid is construed in exceptionally national terms (Tong, “The Maid 女佣 Media Reports”). According to filmmaker, Royston Tan, "[The Maid] will show the world what Singapore can do, and I mean specifically the kind of stories that cannot be made elsewhere in the world. As we 
go along with the globalization trend, everyone is looking out for the uniqueness factor" (Tong, “The Maid 女佣 Media Reports”). Producer Yun sees The Maid as bearing the mark of the nation, even as it remains transnational, when he proudly declares, "After producing over 15 movies, including the successful The Eye and The Eye 2, we feel confident to work with a local director on a local story to produce our very own horror genre. We hope to offer to the international horror fans what The Ring and Nangnak did, but we hope to do so with a Singapore edge" (Tong, "The Maid 女佣 Media Reports"). Director Tong himself also believes that The Maid is a "uniquely Singaporean horror film," but, at the same time, a "universal story" that could draw "audiences everywhere into the skittish eyes of the maid and see the terror tearing her up from within” (“The Maid 女佣 Media Reports”).

But however much The Maid is conceived as a national film, as a film that projects a national self-image, the site in which it is located is a heterogeneous space haunted not only by the specter of Singapore (cinema) history, but, as well, by Philippine (cinema) history embodied by the figure of a Filipina clad in a red cheongsam suspended in the air (see Fig. 9).

The Maid begins with the arrival of 18 -year-old Rosa Dimaano (literally, a rose that cannot be defiled) in the dilapidated house of the Teo family in Singapore. The environment in which Rosa finds herself in is "uniquely Singaporean" in a very important sense. It is the hinterland, the space occupied mainly by the "heartlanders." It is "behind" the high-rise and angular housing estates of the more affluent "cosmopolitans," which Rosa, in the bus on her way to the Teos', describes as "clean" and "wonderful." ${ }^{16}$ It is a hidden and not easily imaginable space in a global or renaissance city - a place out of mind; but it is a grotesque, mysterious, and desolate place suited for a horror tale. Benjamin McKay argues that this space as the "underbelly[... ] acts as a site of Singaporean darkness - the internalized 'other' - and the innocence of Rosa acts as point of continued referential juxtaposition" (McKay 488).

The story of The Maid is centered on a transnational figure, the character of Rosa that is familiar and conceivable at the fulcrum of Philippine-Singapore international relations: for the Singaporean, she is the eponymous maid; for the Filipino, she is the "OFW" or the "overseas Filipino worker." One online userreview in TrashCity.Org registers bewilderment and sarcasm about the seeming loophole in the film's narrative motivation. The reviewer writes, "[Rosa] doggedly sticks at her job well after the point where I'd have handed in my resignation. Such persistence is laudable." ${ }^{17}$ Such a comment does not comprehend the tragedy of the maid as an OFW. Rosa, like hundreds of thousands of OFWs, must work to support her family in the Philippines. Considered from the point-of-view of the Filipino, the foundation of Rosa's cinematic conflict is a key determinant of the uniquely Filipino genre that has come to be known as the "OFW film," another film genre that saw its proliferation in the 1990 s up to the 2000 . 


\section{The OFW Film Cycle}

The OFW film, which is so identified because its generic plot, revolves around the (mostly unfortunate, many times tragic) experience of migrant workers, before, during, or after their stay in another country. The OFW film is a uniquely Filipino (i.e., national) genre, unlike films that have been categorized as "cross-cultural," "accented," "exilic," or even "diasporic," by critics like Hamid Naficy and Laura Marks. With very few exceptions, the OFW film is a national assemblage: produced by the local industry according to the logic of its profitability and overdetermined mode of address, its main emphasis remains to be the domestic market and its extended audience is comprised of Filipinos abroad. And while there are independently produced OFW films that exhibit unconventional modes of storytelling, like the offbeat comedy, La Visa Loca (Mark Meily, Philippines, 2005), and the suspense thriller, Cavite (Neill dela Llana and Ian Gamazon, Philippines, 2005), most mainstream productions are keyed in the generic idiom of the Filipino melodrama, notably Anak (Rory Quintos, Philippines, 200o). The ones produced by the big companies, such as Star Cinema and GMA Films, have tended to feature stars and foreign locations. This means that a good number of these films have relatively bigger budgets, which are risked by the companies because the OFW film has proven to be profitable - another lifeline for the dying industry.

The OFW film, at best, is an ironic genre; at worst, a genre - perceived from another time and space - that never should have existed, but does. On the one hand, by virtue of its target audience and the narrative spaces it contains, it allows, at the very least, for the fantasy of a cognitive map, as conjured by Fredric Jameson, of a world in which the American hegemon has been erased, as protagonists move around and through different regions without paying a thought to the US (315-319). Indeed, while a number of OFW films, such as 'Merika (Gil Portes, Philippines, 1984) and Sana Maulit Muli [May It Happen Again] (Olivia Lamasan, Philippines, 1995), deal with Filipinos who desire to "come home" to the imperial center, more and more OFW films imagine or are set in other states, nations, or regions, such as Italy (Milan [Olivia Lamasan, Philippines, 2004]), Dubai (Dubai [Rory B. Quintos, Philippines, 2005]), Hong Kong (Miss Pinoy [Bona Fajardo, Philippines, 2005), Saudi Arabia (Katas ng Saudi [Jose Javier Reyes, Philippines, 2007]), and England (Caregiver [Chito S. Roño, Philippines, 2008]). At most, pursuing Arjun Appadurai's idea of the imagination as alternative space, it has the potential to clear pockets of "space[s] of contestation in which individuals and groups [could be allowed to] seek to annex the global into their own practices of the modern" (4), constructing worlds that are "chimerical, aesthetic, even fantastic" (35). Independent and noncommercial efforts, such as Lav Diaz's Batang West Side [West Side Kid] (Philippines-USA, 2001) and Sari Dalena and Keith Sicat's Rigodon (Philippines-USA, 2005), are examples of such.

Kritika Kultura 21/22 (2013/2014): -643

(C) Ateneo de Manila University

$<$ http://kritikakultura.ateneo.net> 


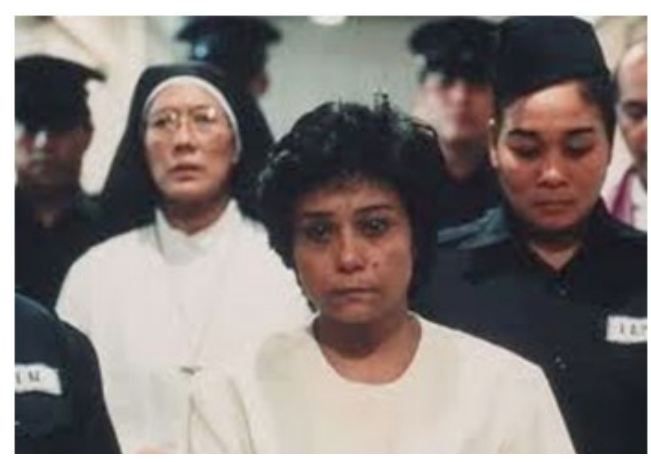

Fig. 8: Philippine superstar, Nora Aunor, plays the role of true-to-life maid, Flor Contemplacion, who was convicted for two counts of murder and hanged in Singapore. An example of the OFW film that rose to productivity in the 1990s, The Flor Contemplacion Story is also one in a series of films about Contemplacion. Photo from Fukuoka Film Archive. ${ }^{18}$
On the other hand, the OFW film's meaningfulness is nothing if not animated by the souls of actual individuals whose bodies are marked twice, first, by nationality and, second, by transnationality. The OFW film is premised on dramatizing and visualizing the impact of the diaspora on Filipinos' everyday lives in and out of the Philippines. The genre's narrative possibilities and cinematic profitability, therefore, are invested on the pains, dangers, and traumas that overseas Filipino workers have had to endure, as they find themselves caught, trapped, or destroyed in the very "trans-" of transnationalism. For a long time, the main destination of Filipino self-motivated emigration was the US, ${ }^{19}$ until the Philippine government under Ferdinand Marcos, in the 1970s, began to promote and regulate labor export (Hau 228). The rapid growth experienced by Asian economies in the 1980 os and 1990 s has also helped institutionalize migrations to countries, like Japan and Singapore, which offer employment for OF Ws (Hau 22830). Eventually, as Caroline Hau asserts, "What was initially viewed as a 'temporary' solution to the Marcos government's inability to work out economic, political, and social solutions to the crisis it encountered in the late seventies and early eighties would eventually become the cornerstone policy, by the [Joseph] Estrada, and [Gloria Macapagal-] Arroyo years, of the Philippine state" (231). Arroyo, before completing her final term as President, even lionized the OFW as hero in cinema, when, through public funds, the Film Development Council of the Philippines produced the musical, Emir (Chito S. Roño, Philippines, 2010).

Moreover, scholars have pointed out that the outward flow of Filipinos through the years has not only multiplied but has also become strikingly feminized and domesticated, signifying how hundreds of thousands of Filipino women now currently occupy very insecure positions (cf. De Guzman; Tadiar; Tyner; Guevarra). Today, the Philippines is one of the largest exporters of labor to over 160 countries. The annual total migrant flows numbered from 50,000 in 1975 to more than a million by 2005, with an average growth rate of 9.8 percent (Orbeta and Abrigo). The concentration of female labor export grew from only 12 percent in 1975 to 47 percent in 1987, after the "People Power Revolution" and during the Corazon Aquino administration, which exalted the OFWs as the "new heroes" of the nation; 
61 percent in 1998, the centennial year of Philippine independence; 72 percent at the turn of the century, in 2001; peaking at a record high of 74 percent in 2004 (De Guzman; Orbeta and Abrigo).

The character and story of Rosa are emblematic of the plight of the "feminized" (not just "female") OFW, and that she exists in the narrative of a box-office hit Singaporean film, distributed all around the world, is an indictment on the Philippine state. Remarkably, De Rossi herself, who is an Italian-Filipina mestiza, was first spotted by Tong in a Filipino "rural" film, Mga Munting Tinig [Small Voices] (Gil Portes, Philippines, 2002), underwritten by the logic of the OFW film. Mga Munting Tinig is about a Manila-educated school teacher, played by de Rossi, who chooses to work in a "backward" rural area against conventional expectations; in the end, however, she finds the heroic gesture unsustainable and succumbs to familial pressure to migrate abroad. De Rossi starred next in Homecoming (Gil Portes, Philippines, 2003) as a "balikbayan" (returnee to the native land) from Toronto, Canada, who unwittingly spreads the SARS epidemic back home and becomes the object (through popular media) of the nation's scorn and terror. After filming The Maid in Singapore, she played the role of a lonely wife searching for her lost OFW husband, in Barcelona (Gil Portes, Philippines, 2006). In these films, de Rossi's body, frail-framed and brown-skinned, is an overdetermined palimpsest of variously inscribed (trans)national imaginaries. The OFW films defined by the presence and performances of her nationally marked body tell conflicted and, ultimately, tragic narratives organized around leaving and homecoming.

Significantly, The Maid is premised exactly on the OFW's leaving and homecoming as well. Why and how Rosa leaves this "clean" and "wonderful" city punctuate Tong's own critique of Singapore status quo, a confounding critique ironically co-produced by the state's Media Development Authority and celebrated as uniquely Singaporean. Singapore, which had launched its vision of turning itself into a global city, in 1995, "miraculously" thrived through the Asian economic crisis, even reaching an economic peak in 1997 and ranking as the fourth richest nation in the world (Seah, "Lagging Behind"). Due to its affluence and proximity, Singapore has been one of the top destinations for OFWs in the last two decades; it was the third major importer of labor export from the Philippines in 2011 (Senate Economic Planning Office, "Overseas Filipino Workers"). Such a state of affairs brands the Filipina in the national imaginary of Singapore as part of its "unique" social conditions and as part of what makes The Maid "uniquely" Singaporean; the figure of the maid is as familiarly and conceivably Filipina as the Lucky Plaza, a local mall which Tong presents in the film as the day-off haven of throngs of Filipina maids.

The nation's rapid economic growth rate, according to Kenneth Paul Tan, is capitalized on the fear-induced and paranoiac productivity-drive of overworked and infantilized Singaporeans, which, in turn, has "brought freedom from basic want for nearly every citizen" (1-9; cf. S. Tan and Fernando 7). What is unspoken, 
of course, is how much the prosperity of Singapore is also dependent upon the "compliant and vulnerable workforce [...] found in the "hinterland" of neighboring countries, including the Philippines, Indonesia, Malaysia, and Sri Lanka, which can export surplus working-class labor to a largely middle-class city-state (McKay 481).

Uncannily, the same year that saw the phenomenal local release of The Maid also saw the publication, in December of 2005, of the global NGO, Human Rights Watch's (HWR), harrowing report entitled, "Maid to Order - Ending Abuses against Migrant Domestic Workers in Singapore," which chronicles the underside of affluence borne by imported domestic labor. The report began by narrating the deaths due to "accidents or suicides" of 147 maids in Singapore from the late 1990 os to the mid-20oos. It claimed, in sum, that a class of domestic employees from neighboring nations has been excluded from the protection afforded by the state's Employment Act, denied access to food and decent pay by their employers, and subjected to physical and emotional abuse (Human Rights Watch, "Maid to Order"). The Maid prefigures this report in the scene of the bizarre and unexplainable drive of Wati, another imported though non-Filipina maid in the film, to climb up a building and jump to her death in broad daylight for all to see. Rosa herself, echoing the HRW report, is terrorized, yelled at, dragged, manhandled, tied down, gagged, burned with live sticks of incense, and hanged by her employers.

The Singapore government said that the 128-page HRW report is "grossly exaggerated" and that an independent poll by Singapore Press Holdings conducted two years earlier revealed that majority of "FDWs" (foreign domestic workers) were happy to work in Singapore ("Singapore Accused of Maid Neglect"). But Tong himself and the local press, in interviews posted in his blog that richly documents the reception of The Maid in 2005, implicitly and explicitly confirm the HRW report, locate the Filipina maid in the Singapore cinema imaginary, and explain the narrative motivations that drive his film. Speaking to a Singaporean interviewer, Tong remarks,

And you know, maids are everywhere, not just in Singapore. There are maids in Hong Kong, Taiwan and now in mainland China. But to me, they are almost invisible. They are not supposed to speak, not supposed to have opinion. They are deprived of all these basic human emotions, and I thought that's a nice angle to tell a horror story from. A maid in Singapore is not allowed to scream or make a big deal when she is frightened, in case her employer thinks she's crazy and sends her back to the Philippines. (“The Maid 女佣 Media Reports")

In another interview, he says,

Working far away from home, maids toil day and night to earn a meager living, suffering many untold abuses. They are cut off from their loved ones, thrust into alien surroundings, expected to share a roof with strangers and then act 
as if everything is normal. It is an extraordinary predicament. (“The Maid 女 佣 Media Reports")

Such statements are transnationally meaningful: they figure the OFW with hyperbolic phrases like, "maids are everywhere," "they toil day and night," or "they suffer many untold abuses." Such hyperboles, on the one hand, have historicomaterial bearings that invoke an abstracted idea of widespread injustice, but, on the other hand, abstracted as narrative figures for currently profitable genre films, like the OFW films or this Singapore horror film. This is clearly the case when such phrases are used in the press in the context of promoting a movie. But these words are also helplessly situated, as when a Singaporean director grants an interview for a Singapore newspaper or magazine. You know, Tong tells his interviewer, that is, as we Singaporeans all know, he says in effect - maids live with strangers, earn meager salaries; they are not supposed to speak or even be frightened; they are everywhere but remain invisible - for us, Singaporeans.

In another newspaper interview, Tong's critique of infantilized Singapore, framed by the idiom of market economics that devastatingly objectifies the Filipina maid, comes through skirting irony as painful tragedy.

Q: Your film will probably scare the beejesus out of Filipinas hoping to work here. What if maid agencies hold you responsible for causing a shortage?

A [Kelvin Tong]: I refer to basic Adam Smith. Supply goes down, demand goes up. Those maid agencies won't suffer. Unit price escalates. It will be all those cash-rich twenty-something newly-weds who will. But serves them right. If they'd rather go to Zouk than spend their weekend ironing and mopping, then they deserve to shell out for the luxury of having bonded servitude.

Q: Why do you reckon so many Singaporeans take such perverse pleasure in scolding, scalding, and scarring maids?

A: [It comes from] a tradition of branding livestock probably. Singaporeans have very few outlets to express their creativity, so perhaps some of them resort to a few well-placed cigarette-butt burns to make themselves feel better after a long, hard day at the office.

I do not know for sure, but mutilating maids is one of the more unusual characteristics of our otherwise-colourless tribe. At least it gives us something to brag about when we are waiting to board a plane along with a bunch of neo-Nazis, Tutsis and Kompassus death-squad commandos. ("The Maid 女 佣 Media Reports")

The sarcasm of Tong is biting and his critique is frontal, but it is also premised on the Filipina branded as commodity, victim, slave, livestock. The same imaginary relations are fleshed out in one of the articles on The Maid, when a feature writer interjects: "We all know that good dramas come from extraordinary predicaments. 
And what better way to tell a uniquely Singaporean tale of horror than through the eyes of a foreign observer" (Tong, “The Maid 女佣 Media Reports”). Such predicaments are extraordinary for Singaporeans and yet widely known and spoken about. An ironically ordinary situation (as far as Tong can see) for the OFW, who, from a differential point-of-view, is summoned spectrally to tell a uniquely Singaporean tale of horror and indictment.

\section{Ghostly Allegory 2 - The Maid}

Rosa, who migrated to Singapore to earn for the medication of her brother who is seriously ill, unwittingly arrives at a time, a season, unknown to foreigners like her - the Chinese "month of the hungry ghosts," when the spirits of the wronged are unleashed in the material world. Rosa, unaware of the secrets and lore for fending off ghosts, endures the hauntings and nightmares, even as she carries on with her work as a domestic maid. Throughout her terrifying experiences, this kind and innocent woman nevertheless develops an affectionate and caring though non-sexual relationship with the "mentally retarded" man-child, Ah Soon, the only son of the Teo house.

As a ghostly allegory of two nations, the film's spectrality trajects in several directions and is ramified through the interior and exterior of the text. In the narrative unfolding, the haunting is relentless for Rosa, a fictive but truly Filipina figure. But, given the film's transnational-historical foundations, the haunting should likewise be unrelenting for the Singaporean. The characterization of Rosa as servile and suffering, as well as Tong's sarcastic critique of Singapore status quo, is founded on the violence of representing the "other," the Filipina, as a mirror for confronting the monstrous and unjust self.

Tong shows how conspiratorial silence perpetuates violence in the way the Teos duplicitously disarm Rosa and make her vulnerable to the "hungry ghosts." When Rosa desperately confesses to the Teos that she can see ghosts, the couple looks at each other knowingly and then tells her that "if you leave them [the ghosts] alone, they will leave you alone." This seems like sound advice for Rosa, but the Teos need her to dismiss the ghosts, whom they know would never leave her alone, because the Teos need more time to carry out their plan to sacrifice her to these very ghosts. Strangers also lurk outside of the Teos' house like shadows that shrink away when Rosa looks to them questioningly, suggesting that everyone, except Rosa herself, knows the kind of monstrosity that happens or has happened inside the haunted house. The only possible help could come from the empathetic postman who shares Rosa's sense of isolation, but he is deaf and mute and helplessly unaware of the situation.

Rosa, in spite of all her efforts to leave the ghosts alone, always sees a woman in red cheongsam hanging lifeless on a rope. Unknown to her, this ghost who haunts her wishes only to be remembered, to be revealed, to be declared, as 
a victim. Toward the end of the film, Rosa learns that this woman is Esther, her predecessor, whom Mrs. Teo misrepresents as having gone "missing" and as being "like many Filipina maids" who "find boyfriend here and run away." This image of Esther, a woman hanged, spectrally summons another (cinematic) historical figure, Flor Contemplacion, a Filipina maid who was convicted of two counts of murder (including the murder of a fellow Filipina maid, Delia Maga), and hanged by the Singapore state in 1995 (see Figure 8). ${ }^{20}$ This detail is significant, since Esther, the ghost that Rosa sees hanging on a rope, was not killed by hanging but by burning. The image of hanging, then, alludes to a historical past outside of the film and foreshadows Rosa's fictive future.

The life-story of Contemplacion was sold for US\$75,00o by her philandering husband and was filmed at least three times in the mid-1990s (Flores 90), fanning the uproar of the Filipino public and raking in profit in the process (cf. Guillermo). This cycle of Contemplacion films, The Flor Contemplacion Story (Joel Lamangan, Philippines, 1995), Victim No.1: Delia Maga (Jesus, Pray for Us!) (Carlo J. Caparas, Philippines, 2005), and Bagong Bayani, OCW [Unsung Heroine] (Tikoy Aguiluz, Philippines, 1995), which provided enough impetus for the cycle of OFW films to carry on through to the 2ooos, was ironically produced alongside the historical dramas on national heroes.

Feeding on the popular sentiment in the Philippines, the aforementioned films generally maintain Contemplacion's innocence. The legal verdict that declared Contemplacion a murderer was never reversed, but her prototypic and now ghostly image of a Filipina hanged in Singapore found its way back to Singaporean imagination exactly ten years later. McKay speculates and rhetorically asks:

By assembling an array of understood metaphors, has Tong not further reinforced a perceived and received identity construction [in The Maid] founded upon the idea of suffering, one that is here sexualized - and is more broadly gendered as female, defiant but innocent and incapable of exerting control over one's own destiny - a victim of the will of others? Does he not, either by inference or in error, personify a rendering of perceived Filipino national identity in the figure of Rosa/Esther? Given the capacity of audiences to be able to contextualize their own reception of this film - bringing to it their broader understanding of the discourse on Filipina labor in Singapore and perhaps their collective awareness and memory of real-life maids such as Flor Contemplacion - can this film ultimately be read in any other way? (491)

The penultimate revelation in The Maid, before the climactic unraveling of heterogeneous space, involves the thematic and dramatic entwining of Rosa, Ah Soon, and the shadowy apparition of Esther, the specter of the Filipina unjustly wronged and violently silenced. Rosa discovers the scorched remains of Esther in a sealed drum and, immediately after, succumbs to a trance beneath the spirit's red 
veil. Esther declares: "I have been talking to you for so long, Rosa. And now you finally hear me. I am free." Esther, as it turns out, was burned to death by Mr. Teo after Ah Soon "innocently" rapes her, and she has returned. The ghost's freedom lies now in her unveiling, and Rosa's newfound knowledge empowers her to fight back.

But her knowledge is not yet complete. She learns, eventually, that Mr. and Mrs. Teo have all along planned to marry their son to the ghost of Esther, as mediated by her (Rosa), before hungry ghost month comes to a close in a few hours. Rosa learns, too, that Ah Soon, unable to bear the grief of Esther's death, jumped to his death and is now returned also as a ghost.

The network of subjectivities, agencies, identities, and representations reaches a climactic complexity in the final revelation. By attempting to murder Rosa, the Teos are forcing the conflation of the Filipina unjustly murdered and the Filipina still filled with vitality. The possibility of such a conflation is based on these Filipina bodies and, at the same time, based on being cast in the same space to reenact the same events. The conflation is partial, only up to the extent that Ah Soon misrecognizes Rosa as Esther for their ethnic-racial likeness, though the Teos would stop at nothing to consummate the unity - not just of the ghost of Esther and the body of Rosa but, in matrimony, of Esther/Rosa and Ah Soon. The price of complete unity is the singular life of Rosa.

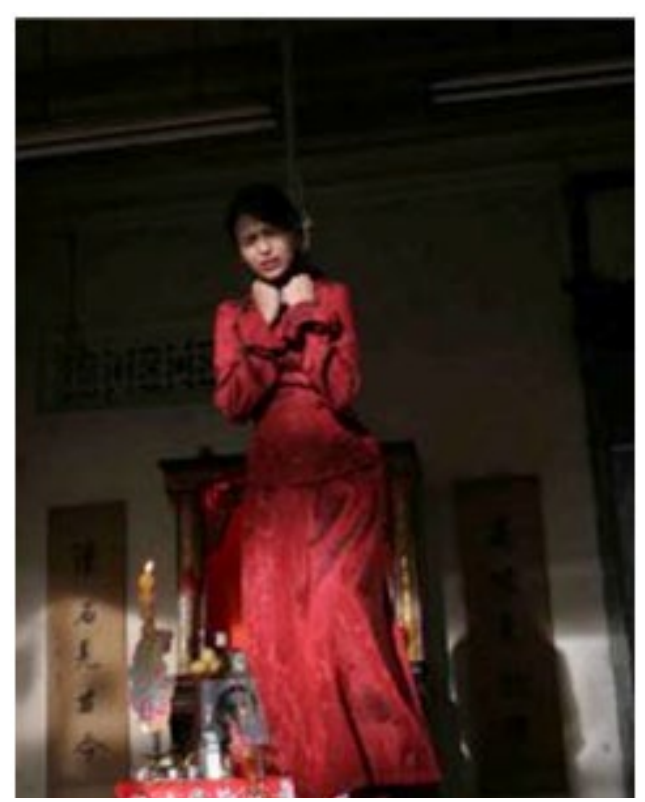

Fig. 9: Rosa Dimaano (Alessandra de Rossi) is being hanged by her Singaporean employers in an attempt to marry her to their ghost son.

This complex network is borne by the generic code of horror and by that spectral allegory that is able to invoke material history. Rosa's final struggle for freedom from the hands of her oppressive employers in the haunted house, for McKay, "becomes the symbolic site for the endurance of Filipina suffering" (490). But the remarkable reversal in Tong's narrative configuration is that, in this house, ultimately, it is the living (Teos) that hound the living (Rosa). Therefore, if the Teos succeed, Rosa's vital individuality will be effaced by the discursive signifier of and symbolic power invested on "the maid"; she will be recast as a kind of ghost of infinite regress, inextricably chained to Esther, Flor Contemplacion, Delia Maga, and others before her, not as Rosa, but, simply, as the maid. She must, therefore, resist the cycle of reenacting past events in the same space. 
The twist in Tong's story is that it is the infantile Ah Soon who had begun the cycle of violence and trauma that saves Rosa. Ah Soon defiled Esther who genuinely loved him. The narrative ambiguities - of whether he recognized his violation or not and whether he recognized Rosa as separate from Esther or not - remain the haunting uncertainties of the film. What is certain, though, is that he will not conspire to let another injustice happen, even at the price of his own father's life. And what is certain is that by cutting the rope, he has severed Esther and the past from Rosa and allowed Rosa to live, regain her own future, and return home.

\section{Hauntings and Homecomings}

Do these ghosts hail from the past, or do they surface from beneath? As Avery Gordon asks, "How do we reckon with what modern history has rendered ghostly" (18)? She asserts, "The ghost is not simply a dead or missing person, but a social figure, and investigating it can lead to that dense site where history and subjectivity make social life" (8); as such, "[to] be haunted is to be tied to historical and social effects" (190). The ghost tales discussed in this essay, configured in the crucible of defining "national" cinemas, have occasioned - like hungry ghost month - the summoning of subjects modernity has abandoned in the dark.

The temporality of haunting is expressed penetratingly in The Echo and The Maid. In both instances, taking cue from Lim, "the haunting repetition of a traumatic past $[. .$.$] renew [\mathrm{s}]$ our sense of responsibility and solidarity toward the injustices endured by those long dead" (150-51). The haunting, if anything is certain, is for the here and now, and ghosts haunt the living.

The temporality of haunting also allows for a critical understanding of how the "national-cinema effect" is enabled and unraveled by spectral time (cf. Lim 182-205). The ghosts summoned in the space between shared "American fantasies" and similar postcolonial experience, generic though they may be, have called (the cinemas of) the Philippines and Singapore into account. And the con-texts of The Echo and The Maid, in all their historical specificities, have highlighted the ambivalence and contradictions of the discourse of "national" cinema.

Significantly, it is the ghost of the Filipina, as she appears in these films - whether conceived as Hollywood, Filipino, or Singaporean, or whether conceived as heroic or horrific - that profoundly indicts and accuses. The nodal and spectral body of the Filipina, in the process of haunting the transnational screen, illuminates the modern drive to maintain state sovereignty (or to merely survive, for the "weak state") even as cultural and economic flows are established and regulated across nation-states. Eminently, the ghost in the midst of transnational exchanges embodies the ideals that nation-formation ought to aspire for.

The ghostly allegories that are The Echo and The Maid are unruly allegories, as ghosts are wont to appear in unexpected and inexplicable ways, and they appear incarnate with stains of dirt and blood and tears on their faces. In one tale, the living 
defies her odds; the dead is fictively made to atone for his sins and the sins of his family - she lives with her dead, while he dies twice over for the living. In the other tale, a racially and nationally marked body leaves - never arriving, never returning, but reappearing instead as an apparition to be unveiled. The haunting in the films is so fundamental as to render both tales interchangeable, but the ghosts haunt moments and spaces so specific that they are singular in spite of being generic. In both tales, ghosts return there as specters, and yet call forth from here - haunting the living, beckoning the dying home. Contemporary transnational cinemas are, by turns of discursive recesses and resurgences, entranced by non-contemporaneous temporality - in some instances, as with The Echo and The Maid, we find that colonial history is rehearsed, regional transgressions are redressed, and abuses sustained and condoned in the name of nation/cinema are revealed; and all from within the very (neo)colonial spaces, above the underside of modernity, which render them hideous, but true. 


\section{Notes}

1. I adapt this notion of "con-text" partly from Paul Ricœur's $(1981 ; 1984)$ idea that the relationship between historical human action and its configuration in art and narrative is not a relationship of text-context but a relationship of prefiguringconfiguring-refiguring. This implies that a given work actually refigures and not only reflects history, thereby associating aesthetics with ethical and political action. In this case, the critical project is to articulate the ethical and political dimensions of cinema's refiguring of history between nation-states.

2. For Hunt and Leung, "A transvergent cinema suggests that no cinema is a complete a-priori artefact in and of itself. This cinema [...] crosses lines, zigzags, derails, rerails, reroutes, jumps from one continent to another, relies on artifice to create its imaginary spaces" (Hunt and Wing-Fai 3).

3. Acknowledgment must go to Lucenio Martin Lauzon for providing this researcher with yet unpublished filmographies of Filipino films from 2001-2002.

4. Jose Nepomuceno, coming in sequence before Salumbides is generally considered as "the father of Philippine cinema." As an artist, his aesthetics is not based on Hollywood but on the Spanish theatrical form of the zarzuela and its Filipino adaptation into the sarsuwela. See Deocampo, Cine.

5. The web address is <http://www.cineplex.com/Movies/Archives/CS41492/TheGreat-Raid/Photo.aspx?id=223403>.

6. Accessed 23 August 2011.

7. The web addresses are <http://www.kabayancentral.com/video/star/cpstsukob. html > and <http://www.kabayancentral.com/video/star/cpstpasukob.html> respectively, both accessed 13 April 2013.

8. This was done through the website, <http://www.echothemovie.com>, maintained by webmaster and film editor, Chuck Gutierrez. This website is no longer up.

9. Unless otherwise noted, all citations and quotations from the entries and comments on Yam Laranas's blog are culled from <http://yamlaranas.blogspot. com>. Information cited and quoted from this blog is parenthetically indicated as "Laranas Blogspot."

10. I use "fantasy-production" here, with reference to Neferti X.M. Tadiar's notion of "fantasies," which are "hegemonic forms of expression of our desiringactions" and "the abstract forms into which work becomes subsumed within the world-system of production" (6). She argues that the social fantasies that generate national imaginaries are inextricably linked with the confluence of state hegemony and the "New World Order" that situate individual (feminized) subjects (7). She, moreover, demarcates "the international media system" as "the source of many of our interpenetrative representations of the world, [which] plays a constitutive and paradigmatic role" in this global order (6). In short, such fantasies, in insidious and assiduous ways, animate the transnationality of cinema cultures, as exemplified by the activity in the blog of Laranas.

11. The web address is $<$ http://www.aceshowbiz.com/still/oooo3878/the_echo11. html $>$, accessed 13 April 2013. 
12. The web address is <http://www.aceshowbiz.com/still/oooo3878/the_echoo2. html $>$, accessed 13 April 2013.

13. Unless otherwise noted, all citations and quotations from reviews and interviews published in the Singapore press regarding The Maid are culled from Kelvin Tong's blog, particularly, the page “The Maid 女佣 Media Reports” <http:// kelvintong.wordpress.com/2005/o9/10/the-maid-media-reports/>, accessed 13 April 2011. The page features a wealth of materials from different magazines and newspapers that are not sufficiently documented and that are posted in the form of clippings. Information cited and quoted from this blog page is parenthetically indicated as "The Maid Media Reports".

14. The official website of Raintree Pictures is $<$ http://www1.mediacorp.sg/raintree $>$, accessed 9 April 2013.

15. In contrast, contemporary rhetoric on Philippine cinema, if one notes the current lionization in critical circles and popular media of the rise of the "indie" (i.e., independent productions) as world-class cinema, insists on downplaying the notion of film as a commercial product and insists that "uncompromised" Filipino films should be regarded in cultural rather than economic terms.

16. Prime Minister Goh Chok Tong (1999-2004) divides Singaporeans between "cosmopolitans," who "produce goods and services for the global market, use Singapore as a base to operate in the region, and can work and be comfortable anywhere in the world, and "heartlanders," such as "taxi-drivers, stallholders, provision shop owners, production workers and contractors," who, if "they emigrate to America, will probably settle in Chinatown, open a Chinese restaurant and call it 'eating house.' Such a division is problematized by S.K. Tan and Fernando (126-132) vis-à-vis Singapore cinema and K.P. Tan (63-70) vis-à-vis art in Singapore.

17. This is quoted from <http://www.trashcity.org/BLITZ/BLIT1687.HTM $>$, accessed 8 April 2011.

18. The web address is $<$ http://www.city.fukuoka.lg.jp/fu-a/en/film_archives/ detail/232.html>, accessed 13 April 2013.

19. Though this "self-motivated" emigration could be viewed, as Espiritu argues convincingly and as I mentioned in the first section, as first initiated by colonial contact. Espiritu summarizes it provocatively, thus: "Filipinos went to the United States because Americans went first to the Philippines" (25).

2o. For an illuminating discussion on the background of Flor Contemplacion and the "cycle" of films that her life and death have fueled, see Guillermo.

\section{Works Cited}

Abramowitz, Rachel and Sheigh Crabtree. "Hollywood Horror Films Suffer Box Office Anemia." Los Angeles Times, 9 June 2007. Web. 27 May 2013.

Aguiluz, Tikoy, dir. Bagong Bayani, OCW [Unsung Heroine]. Scriptwriter Jose F. Lacaba. Perf. Helen Gamboa, Dennis Marasigan, Irma Adlawan. Dark Horse Pictures, 1995. Film. 
--, dir. Rizal Sa Dapitan. Scriptwriters Jose F. Lacaba, Vic Torres. Perf. Albert Martinez, Amanda Page, Roy Alvarez, Jaime Fabregas. Independent Cinema Association of the Philippines, 1997. Film.

Appadurai, Arjun. Modernity at Large: Cultural Dimensions of Globalization. Minneapolis: U of Minnesota P, 1996. Print.

Avellana, Joe Mari, dir. Damong Ligaw. Scriptwriter Joe Mari Avellana. Perf. Romnick Sarmenta, Beth Tamayo, Ronnie Lazaro and Robert Arevalo. Premier Productions, 1998. Film.

--, dir. Emilio Aguinaldo. Perf. Jorge Estregan, Rio Locsin, Elizabeth Oropesa. GMA Films, 1998. Film.

Bereson, Ruth. "Renaissance or Regurgitation? Arts Policy in Singapore 1957-2003." Asia Pacific Journal of Arts and Cultural Management 1.1 (2003): 1-14. Print.

Berry, Chris. "From National Cinema to Cinema and the National: Chinese-Language Cinema and Hou Hsiao-Hsien's 'Taiwan Trilogy"' Theorizing National Cinema. Ed. Valentina Vitali and Paul Willemen. London: British Film Institute, 2006. 148-57. Print.

Campomanes, Oscar. “The New Empire's Forgetful and Forgotten Citizens: Unrepresentability and Unassimilability in Filipino American Postcolonialities." Critical Mass: A Journal of Asian American Cultural Criticism 2.2 (1995): 145-20o. Print.

Caparas, Carlo J., dir. Tirad Pass: The Story of Gen. Gregorio del Pilar. Perf. Romnick Sarmenta, Joel Torre, Gretche Barreto. Donna Villa, 1996. Film.

---, dir. Victim No. 1: Delia Maga. Perf. Gina Alajar, Joel Torre. Donna Villa, 1997. Film.

Capino, Jose B. Dream Factories of a Former Colony: American Fantasies, Philippine Cinema. Minneapolis: U of Minnesota P, 2010. Print.

Comaroff, Jean and John Comaroff. "Alien-Nation: Zombies, Immigrants, and Millenial Capitalism." The South Atlantic Quarterly 104.4 (2002): 779-805. Print.

Coppola, Francis Ford, dir. Apocalypse Now. Scriptwriters John Milius, Francis Ford Coppola. Perf. Martin Sheen, Marlon Brando, Robert Duvall. Zoetrope Studios, 1979. Film.

Cordova, Fred. Filipinos, Forgotten Asian Americans: A Pictorial Essay, 1763-circa 1963. Iowa: Kendall/Hunt Publishing Company, 1983. Print.

Dahl, John, dir. The Great Raid. Scriptwriters William Breuer, Hampton Sides. Perf. Benjamin Bratt, Joseph Fiennes, James Franco, Robert Mammone. Miramax Films, 2005. Film.

Dalena, Sari Raissa Lluch, and Keith Sicat, dirs. and scriptwriters. Rigodon. Perf. Joel Torre, Arthur Acuña, Chin Chin Gutierrez. First Quarter Storm Productions, 2005. Film.

De Guzman, Odine. "Overseas Filipino Workers, Labor Circulation in Southeast Asia, and the (Mis)management of Overseas Migration Programs." Kyoto Review of Southeast Asia. 4 (2003). Web. 30 Mar. 2013.

Dela Llana, Neill, and Ian Gamazon, dirs. Cavite. Perf. Ian Gamazon, Edwin Lagda, Edgar Tangcangco, Norma Tangcangco, Quynn Ton, Mariza Levario, Neill de la Llana. Gorilla Films, 2005. Film. 
Deocampo, Nick. Cine: Spanish Influences on Early Cinema in the Philippines. Manila: National Commission for Culture and the Arts, 2003. Print.

--. Film: American Influences on Philippine Cinema. Mandaluyong City: Anvil, 2011. Print.

Deramas, Wenn V., dir. Pasukob. Scriptwriters Wenn V. Deramas, Mel Rosario. Perf. Ai-ai Delas alas, Ruffa Mae Quinto, Allan K, Antonio Aquitania. Octoarts Films, 2007. Film.

Derrida, Jacques. Specters of Marx: The State of the Debt, the Work of Mourning, and the New International. Trans. Peggy Kamuf. New York: Routledge, 1994. Print.

Diaz, Lav, dir. and scriptwriter. Batang West Side. Perf. Joel Torre, Yul Servo, Gloria Diaz. Precilla Almeda. Jimon Productions, 2001. Film.

Diaz-Abaya, Marilou, dir. José Rizal. Scriptwriters Ricardo Lee, Jun Lana, Peter Ong Lim. Perf. Cesar Montano, Joel Torre, Jamie Fabregas, Gloria Diaz, Gardo Versoza, Monique Wilson. GMA Films, 1998. Film.

Durovicová, Natasa and Kathleen Newman, eds. World Cinemas, Transnational Perspectives. New York: Routledge, 2010. Print.

--.. Preface. Durovicová and Newman ix-xv. Print.

Espiritu, Yen Le. Home Bound: Filipino American Lives Across Cultures, Communities, and Countries. Berkeley: U of California P, 2003. Print.

Fajardo, Bona, dir. Miss Pinoy. Scriptwriters Lyn Fajardo, Bona Fajardo. Perf. Judy Ann Santos, Noni Buencamino, Glaiza De Castro. Blue Art Productions, 2005. Film.

Flores, Patrick. "The Dissemination of Nora Aunor." Tolentino 77-95. Print.

Gilroy, Tony, dir. The Bourne Legacy. Scriptwriters Tony Gilroy, Dan Gilroy. Perf. Jeremy Renner, Rachel Weisz. Universal Pictures, 2012. Film.

Goldstone, Richard, and John Jr. Monks, dirs. No Man Is an Island. Scriptwriters Richard Goldstone, John Monks. Perf. Jeffrey Hunter, Marshall Thompson, Barbara Perez, Ronald Remy. Gold Coast Productions, 1962. Film.

Gordon, Avery F. Ghostly Matters: Haunting and the Sociological Imagination. Minneapolis: U of Minnesota P, 2008. Print.

Guevarra, Anna Romina. Marketing Dreams, Manufacturing Heroes: The Transnational Labor Brokering of Filipino Workers. New Brunswick: Rutgers UP, 2009. Print.

Guillermo, Alice G. "The Filipina OCW in Extremis." Tolentino 106-24. Print.

Hau, Caroline. On the Subject of the Nation: Filipino Writings from the Margins, 1981 to 2004. Quezon City: Ateneo de Manila UP, 2004. Print.

Hawkins, Michael Gary. Co-Producing the Postcolonial: U.S.-Philippine Cinematic Relations, 1946-1986. Los Angeles: U of California, Los Angeles, ProQuest, UMI Dissertations Publishing, 2008. Print.

Hjort, Mette, and Duncan Petrie. Introduction. Hjort and Petrie 1-19. Print. --- , eds. The Cinema of Small Nations. Edinburgh: Edinburgh UP, 2007. Print.

Hjort, Mette, and Scott MacKenzie, eds. Introduction. Cinema and Nation. London: Routledge, 2000. 1-14. Print.

Human Rights Watch. "Maid to Order - Ending Abuses against Migrant Domestic Workers in Singapore."Human Rights Watch. 7 Dec. 2005. Web. 11 Apr. 2013.

Hunt, Leon and Leung Wing-Fai. Introduction. East Asian Cinemas: Exploring Transnational Connections on Film. Eds. Leon Hunt and Leung Wing-Fai. London: Tauris, 2008. 1-13. Print. 
Jameson, Fredric. “Globalization and Hybridization.” Durovicová and Newman 315-19. Print.

Kwak, Jae-young, dir. My Sassy Girl. Scriptwriter Ho-sik Kim. Perf. Tae-hyun Cha, Gianna Jun, In-mum Kim, Wok-suk Song. Shin Cine Communications, 2001. Film.

Lamangan, Joel, dir. The Flor Contemplacion Story. Scriptwriter Bonifacio Ilagan, Ricardo Lee. Perf. Nora Aunor, Amy Austria, Rita Avila. Viva Films, 1995. Film.

Lamasan, Olivia M., dir. Milan. Scriptwriter Raymond Lee. Perf. Claudine Barretto, Piolo Pascual. Star Cinema Productions, 2004. Film.

--, dir. Sana Maulit Muli. Scriptwriters Jose Javier Reyes, Olivia M. Lamasan. Perf. Aga Muhlach, Lea Salonga, William Maritnez. Star Cinema Productions, 1995. Film.

Laranas, Yam, dir. The Echo. Scriptwriters Roy Iglesias, Yam Laranas. Perf. Jomari Yllana, Richard Gutierrez, Iza Calzado. Regal Films, 2005. Film.

--. Yam Laranas. Blogspot, 21 Dec. 2005. Web. 22 Aug. 2011.

Lim, Bliss Cua. Translating Time: Cinema, the Fantastic, and Temporal Critique. Quezon City: Ateneo de Manila UP, 2011. Print.

Lo, Kwai-cheung. Chinese Face/Off: The Transnational Popular Culture of Hong Kong. Urbana: U of Illinois P, 2005. Print.

Marks, Laura U. The Skin of the Film. Durham: Duke UP, 20oo. Print

McCabe, Colin. Introduction. The Geopolitical Aesthetic: Cinema and Space in the World System. By Fredric Jameson. Bloomington: Indiana UP, 1995. ix-xvi. Print.

McKay, Benjamin. "The Politics of Mirrored Metaphors: Flor Contemplacion and The Maid." Positions: East Asia Cultures Critique 19.2 (2011): 463-98. Print.

Meily, Mark, dir. La Visa Loca. Scriptwriter Mark Meily. Perf. Robin Padilla, Johnny Delgado, Rufa Mae Quinto. Unitel Pictures, 2005. Film.

MICA (Ministry of Information, Communication, and the Arts). Creative Industries Development Strategy. Singapore, 2002. Web. 10 Apr. 2013.

Miller, Toby, Nitin Govil, John McMurria, Richard Maxwell, and Ting Wang. Global Hollywood 2. London: British Film Institute, 2005. Print.

Millet, Raphaël. Singapore Cinema. Singapore: Didier Millet, 2006. Print.

Naficy, Hamid. An Accented Cinema: Exilic and Diasporic Filmmaking. Princeton: Princeton UP, 2001. Print.

Nakata, Hideo dir. Ring. Scriptwriter Hiroshi Takahasi, Koji Suzuki. Perf. Nanako Matsushima, Miki Nakatani, Yuko Takeuchi, Hitomi Sato. Asmik Ace Entertainment, 1998. Film.

Namibutr, Nonzee, dir. Nang Nak. Scriptwriter Wisit Sasanatieng. Perf. Inthira Charoenpura, Winai Kraibutr, Manit Meekaewjaroen. Tai Entertainment, 1999. Film.

O’Hara, Mario, dir. and scriptwriter. Sisa. Perf. Gardo Versoza, Aya Medel, Patrick Guzman, Marcus Madrigal. Regal Films, 1998. Film.

Orbeta, Aniceto Jr., and Michael Abrigo. "Philippine International Labour Migration in the Past 30 Years: Trends and Prospects." Philippine Institute for Development Studies Discussion Paper Series 2009-33. 2009. Web. 10 Apr. 2013.

Pilar, Santiago A. "The Old Movie Melons and Lemons." Filipino Heritage 9. Ed. Alfredo R. Roces. Quezon City: Lahing Pilipino, 1978. 2470-77. Print.

Portes, Gil, dir. Barcelona. Perf. Alessandra de Rosi, Luis Alandi. G5 Media Productions, 2006. Film. 
---, dir. Homecoming. Scriptwriters Adolfo Alix Jr., Gil Portes, Senedy Que. Perf.

Alessandra de Rosi, Elizabeth Oropesa, Bembol Roco. Cinema Partners, 2003. Film.

---, dir. Mga Munting Tinig. Scriptwriters Adolfo Alix Jr., Gil Portes. Senedy Que. Perf.

Alessandra de Rosi, Dexter Doria, Gina Alajar, Amy Austria. Teamwork Productions, 2002. Film.

Quintos, Rory B., dir. Anak. Scriptwriters Raymond Lee, Ricardo Lee. Perf. Claudine Barreto, Vilma Santos, Joel Torre. Star Cinema Productions, 200o. Film.

--, dir. Dubai. Scriptwriter Ricardo Lee. Perf. Aga Muhlach, Claudine Barreto, John Lloyd Cruz. Star Cinema Productions, 2005. Film.

Red, Raymond, dir. Bayani. Scriptwriter Raymond Red. Perf. Raymond Alsona, Grace Amilbagsa, John Arcilla. Janetzko Film, 1992. Film.

--, dir. Sakay. Scriptwriter Ian Victoriano, Raymond Red. Perf. Julio Diaz, Tetchie Agbayani, Leopoldo Salcedo. Alpha Omega Productions, 1993. Film.

Reyes, Jose Javier, dir. Katas Ng Saudi. Scriptwriter Jose Javier Reyes. Perf. Lorna Tolentino, Bayani Agbayani, Vangie Labalan. Maverick Films. 2007. Film.

Ricœur, Paul. Time and Narrative. Trans. Kathleen McLaughlin and David Pellauer. Chicago: U of Chicago P, 1984. Print.

--.. "The Narrative Function." Hermeneutics and the Human Sciences. Ed. Paul Ricœur. Cambridge: Cambridge UP, 1981. 274-296. Print.

Roño, Chito S., dir. Caregiver. Perf. Sharon Cuneta, John Estrada, Rica Peralejo. Star Cinema Productions, 2008. Film.

--, dir. Feng Shui. Scriptwriters Chito S. Roño, Roy Iglesias. Perf. Kris Aquino, Jay Manalo, Lotlot De Leon. Star Cinema Productions, 2004. Film.

--. Motion Pictures in the Philippines. Manila: V.S., 1952. Print.

---, dir. and scriptwriter. T2. Maricel Soriano, Mika dela Cruz, Derek Ramsay. Star Cinema Productions, 2009. Film.

--, dir. and scriptwriter. The Wedding Curse. Perf. Kris Aquino, Claudine Barretto, Wendell Ramos. Star Cinema Productions, 2006. Film.

Said, Edward. Culture and Imperialism. New York: Vintage, 1993. Print.

Salumbides, Vicente, dir. Miracles of Love. Perf. Juanita Angeles, Jose Carvajal, Dimples Cooper. 1925. Film.

San Juan, E. Jr. From Exile to Diaspora: Versions of the Filipino Experience in the United States. Colorado: Westview, 1998. Print.

--.. "Mapping the Boundaries: The Filipino Writer in the US." Journal of Ethnic Studies 19.1 (1991): 117-31. Print.

Seah, Chiang Nee. "Lagging Behind in the Ranking Game." The Star (Malaysia.

Reproduced on the Singapore Window Resource. 10 July 2005. Web. 12 Apr. 2013.

Senate Economic Planning Office. "Overseas Filipino Workers at a Glance." Senate of the Philippines. Senate of the Philippines, May 2012. Web. 4 Apr. 2013

Shohat, Ella, and Robert Stam, eds. Introduction. Multiculturalism, Postcoloniality, and

Transnational Media. New Brunswick: Rutgers UP, 2003. 1-17. Print.

Siddique, Sophia. Images of the City-Nation: Singapore Cinema in the 199os. U of Southern California P, 2001. Print.

"Singapore Accused of Maid Neglect." BBC News, 6 Dec. 2005. Web. 11 Apr. 2013. 
Tadiar, Neferti X. M. Fantasy-Production: Sexual Economies and Other Philippine Consequences for the New World Order. Quezon City: Ateneo de Manila UP, 2004. Print.

Tan, See Kam and Jeremy Fernando. "Singapore." Hjort and Petrie 127-43. Print.

Tan, Kenneth Paul. Cinema and Television in Singapore: Resistance in One Dimension. Leiden: Koninklijke Brill, 2008. Print.

Tiongson, Nicanor G. "The Best of Times, the Worst of Times: The Filipino Cinema in 1990-1999." The Urian Anthology 1990-1999. Ed. Nicanor G. Tiongson. Quezon City: U of the Philippines P, 2010. 2-41. Print.

Tolentino, Rolando B. Geopolitics of the Visible: Essays on Philippine Film Cultures. Quezon City: Ateneo de Manila UP, 20oo. Print.

Tong, Kelvin, dir. The Maid. Scriptwriter Kelvin Tong. Perf. Alessandra de Rossi, Huifang Hong, Benny Soh. Dream Movie Entertainment Ltd., Raintree Pictures, 2005. Film.

--.. “The Maid 女佣 Media Reports.” Kelvin Tong. WordPress, 13 Apr. 2011. Web. 15 July 2013.

Tyner, James A. Made in the Philippines: Gendered Discourses and the Making of Migrants. New York: RoutledgeCurzon, 2004. Print.

Uhde, Jan, and Yvonne Ng Uhde. Latent Images: Film in Singapore. Singapore: Ridge, 2010. Print.

Verbinski, Gore, dir. The Ring. Scriptwriter Ehren Kruger. Perf. Naomi Watts, Martin Henderson, David Dorfman. DreamWorks SKG, 2002. Film.

Villasanta, Julianito V. Tio Ticong: Pelikula at Pulitika: Vicente Salumbides. Manila: U of Santo Tomas Pub. House, 2002. Print.

Xu, Gary G. "Remaking East Asia, Outsourcing Hollywood." Hunt and Leung 191-202. Print. 